\title{
PENERAPAN PRINSIP INDIVIDUALISASI PIDANA DALAM PERKARA TINDAK PIDANA PERPAJAKAN
}

\author{
Subaidah Ratna Juita, Amri Panahatan Sihotang, Supriyadi Supriyadi \\ Fakultas Hukum, Universitas Semarang, Semarang \\ ratna.juita@usm.ac.id
}

\begin{abstract}
Abstrak
Tujuan dilakukannya penelitian ini adalah untuk menganalisis permasalahan yang berkaitan dengan penerapan prinsip individualisasi pidana melalui pemidanaan terhadap pelaku tindak pidana perpajakan dalam putusan hakim. Jenis Penelitian ini adalah yuridis normatif. Data yang digunakan dalam penelitian ini adalah data sekunder. Metode analisis data menggunakan analisis deskriptif yang dikaji berdasarkan obyek kajian hukum pidana tentang penerapan sanksi pidana dalam putusan hakim yang dikaitkan dengan prinsip individualisasi pidana. Analisis mendalam terhadap Putusan MA No. 938 K/Pid.Sus/2015 yang sudah berkekuatan hukum tetap (inkracht van gewijsde) difokuskan pada penerapan prinsip individualisasi pidana melalui pemidanaan terhadap pelaku tindak pidana perpajakan. Hasil penelitian ini adalah penerapan ide individualisasi pidana yang dituangkan melalui pemidanaan terhadap Pelaku Tindak Pidana Perpajakan dalam Putusan MA No. 938 K/Pid.Sus/2015 didasarkan pada adanya kesalahan pelaku, dan elastisitas pemidanaan yang didasarkan pada perubahan/perkembangan/perbaikan pada diri pelaku sendiri. Penerapan prinsip individualisasi pidana melalui pemidanaan terhadap pelaku tindak pidana perpajakan dalam putusan hakim perlu dilakukan melalui pendekatan humanistik pada pelaku tindak pidana perpajakan, dan tidak hanya harus sesuai dengan nilai-nilai kemanusiaan yang beradab, tetapi juga harus dapat membangkitkan kesadaran pelaku akan nilai-nilai kemanusian dan nilai-nilai pergaulan hidup bermasyarakat.
\end{abstract}

Kata kunci: Individualisasi Pidana; Tindak Pidana Perpajakan; Putusan Hakim 


\title{
APPLICATION OF CRIMINAL INDIVIDUALIZATION PRINCIPLES IN THE CASE OF TAX CRIMES
}

\author{
Subaidah Ratna Juita, Amri Panahatan Sihotang, Supriyadi Supriyadi \\ Faculty of Law, Semarang University, Semarang \\ ratna.juita@usm.ac.id
}

\begin{abstract}
The purpose of this research is to analyze the problems related to the application of the principle of criminal individualization through the punishment of tax offenders in the judge's decision. This type of research is normative juridical. The data used in this research is secondary data. Secondary data were obtained through legislation, judges' decisions, books, and scientific journals. The method of data analysis uses descriptive analysis which is assessed based on the object of criminal law study regarding the application of criminal sanctions in a judge's decision that is related to the principle of criminal individualization. In this study, an in-depth analysis of MA Decision No. 938 K / Pid.Sus / 2015 which has permanent legal force (inkracht van gewijsde) is focused on the application of the principle of criminal individualization through the punishment of perpetrators of tax crime. The results of this study are the application of the idea of criminal individualization as outlined by the criminal prosecution of Taxation Actors in the Supreme Court Decree No. 938 K/ Pid. Sus $/ 2015$ is based on the perpetrators' mistakes, and the criminality elasticity is based on changes / developments / improvements in the perpetrators themselves. The application of the principle of criminal individualization through the punishment of tax offenders in the judge's ruling needs to be done through a humanistic approach to taxation offenders, and not only must be in accordance with civilized human values, but must also be able to raise awareness of perpetrators of humanitarian values and the values of community life.
\end{abstract}

Keywords: Criminal Individualization; Tax Criminal Acts; The Judge's Decision 


\section{PENDAHULUAN}

\section{A. Latar Belakang}

Dimuatnya sanksi pidana dalam suatu undang-undang merupakan konsekuensi dari dianutnya asas legalitas dalam sistem hukum di Indonesia. Asas legalitas memiliki makna Nullum crimen, nulla peona sine lege scripta, yaitu tidak ada perbuatan pidana, tidak ada pidana tanpa undang-undang tertulis. Menurut Eddy OS Hiariej, bahwa prinsip tersebut menimbulkan konsekuensi dari makna tersebut adalah harus tertulisnya semua ketentuan pidana. Dengan kata lain, perbuatan yang dilarang maupun pidana yang diancam terhadap perbuatan yang dilarang, harus tertulis secara expresiv verbis dalam undang-undang. ${ }^{1}$

Sejalan dengan hal ini, Sudarto berpendapat bahwa pidana adalah penderitaan yang sengaja dibebankan kepada orang yang melakukan perbuatan yang memenuhi syarat-syarat tertentu. Sedang Roeslan Saleh menyatakan bahwa pidana adalah reaksi atas delik dan ini berujud suatu nestapa yang dengan sengaja ditimpakan negara kepada pembuat delik. ${ }^{2}$ Pidana merupakan salah satu dari tiga masalah pokok dalam hukum pidana, selain masalah pertanggungjawaban pidana, dan masalah tindak pidana. Pidana menjadi ciri khusus dalam hukum pidana dan membedakan secara tajam dari jenis hukum yang lain. Pidana berarti memberikan kenestapaan, kesengsaraan atau penderitaan yang dikenakan terhadap pelaku tindak pidana ${ }^{3}$ Hal ini sesuai dengan pernyataan Van Bemmelen yang menyatakan "hukum pidana menentukan sanksi terhadap pelanggaran peraturan larangan. Sanksi itu dalam prinsipnya terdiri atas penambahan penderitaan dengan sengaja". ${ }^{4}$

Pendekatan humanistik menuntut pula diperhatikannya ide individuliasasi pidana dalam kebijakan/pembaharuan hukum pidana. Ide individualisasi pidana ini mengandung beberapa karakteristik sebagai berikut:

${ }^{1}$ Eddy OS. Hiariej, Asas Legalitas \& Penemuan Hukum Dalam Hukum Pidana, (Jakarta: Erlangga, 2009), hal 4.

2 Muladi dan Barda Nawawi Arief, Teori-Teori dan Kebijakan Hukum Pidana, (Bandung: Alumni. 1984), hal 2.

${ }^{3}$ Ibid.

${ }^{4}$ Roeslan Saleh, Perbuatan Pidana dan Pertanggungjawaban Pidana Dua Pengertian Dasar Dalam Hukum Pidana, (Jakarta: Aksara Baru, 1983), hal 75. 
a. pertanggungjawaban pidana bersifat pribadi atau perorangan (asas personal).

b. pidana hanya dapat diberikan kepada orang yang bersalah (asas culpabilitas).

c. pidana harus disesuaikan dengan karakteristik dan kondisi pelaku, yang berarti ada kelonggaran bagi hakim untuk memilih sanksi pidana dan harus ada kemungkinan modifikasi pidana berupa penyesuaian dalam pelaksanaannya. ${ }^{5}$

Penelitian ini terkait juga dengan penelitian yang dilakukan oleh Y. A. Triana Ohoiwutun \& Samsudi (2017) yang membahas prisnsip individualisasi tehadap kasus narkoba anak. Penelitian tersebut membahas kasus pidana narkoba terhadap anak penjatuhan sanksi pidana penjara tanpa tindakan rehabilitasi terhadap anak pengguna narkotika tidak sejalan dengan tujuan pemidanaan. Prinsip individualisasi pidana dan prinsip double track system sebenarnya dapat diterapkan dalam kasus tindak pidana narkotika oleh pelaku anak. Hakim dalam menjatuhkan sanksi terhadap anak seharusnya berorientasi pada prinsip kepentingan terbaik bagi anak, sehingga pemidanaan terhadap anak, khususnya pidana perampasan kemerdekaan digunakan sebagai upaya terakhir (ultimum remedium). ${ }^{6}$

Sedangkan penelitian oleh C. Maya Indah (2014) dalam penelitiannya menyimpulkan bahwa hakim belum sepenuhnya dalam memutus perkara tindak pidana anak, hakim belum sepenuhnya mengintrodusir prinsip individualisasi pidana. Hakim cenderung menjatuhkan pidana penjara daripada tindakan, dan penjatuhan penjara jangka pendek juga lebih banyak diputuskan hakim daripada orientasi pada jalur tindakan. Pada beberapa fakta, pertimbangan hakim mengabaikan hasil penelitian kemasyarakatan. Tingginya disparitas pidana karena belum adanya pola pemidaanaan menjadikan prinsip individualisasi pidana belum sepenuhnya diterapkan. Dalam rangka penerapan

\footnotetext{
5 Ahmad Bahiej, "Prinsip Individualisasi Pidana dalam Pembaharuan Hukum Pidana Materiel Indonesia”, Jurnal Sosio-Religia, Vol. 3 No. 4, Agustus 2004.

6 Y. A. Triana Ohoiwutun \& Samsudi, Penerapan Prinsip "Kepentingan Terbaik Bagi Anak" Dalam Kasus Tindak Pidana Narkotika, Jurnal Yudisial, Vol 10 No. 1, Komisi Yudisial RI, 2017, Jakarta, hal 189. http://dx.doi.org/10.29123/jy.v10i1.41
} 
prinsip individualisasi pidana, maka pemaknaan hakim pada teks juridis, hendaknya juga mempertimbangkan aspek kefilsafatan dan sosiologikal, untuk membaca makna tersembunyi teks dalam kasus konkrit yang sedang diputuskannya demi kepentingan terbaik anak. ${ }^{7}$

Tri Wahyuni Wiidiastuti (2010) dalam penelitiannya ini lebih fokus membahas bagaimana pendekatan humanistik dalam penggunaan sanksi pidana, tidak hanya berarti bahwa pidana yang dikenakan pada si pelaku/pembuat harus sesuai dengan nilai-nilai kemanusiaan yang beradab, tetapi juga harus dapat membangkitkan kesadaran si pelaku/pembuat akan nilai-nilai kemanusian dan nilai-nilai pergaulan hidup bermasyarakat. Pendekatan yang berorientasi pada nilai humanistik inilah yang menghendaki diperhatikannya prinsip individualisasi pidana dalam penggunaan sanksi pidana sebagai salah satu sarana penanggulangan kejahatan. ${ }^{8}$ Beberapa karakteristik prinsip individualisasi pidana menurut Barda Nawawi Arief adalah :

1. Pertanggungjawaban (pidana) bersifat pribadi/perorangan (asas personal). Orang yang bersalah melakukan tindak pidanalah yang harus bertanggung jawab atas perbuatannya dan tidak dapat diwakili oleh orang lain.

2. Pidana hanya diberikan kepada orang yang bersalah (asas culpabilitas). Hal ini berarti bahwa orang yang melakukan tindak pidana dengan kesalahanlah yang dapat dipidana. Kesalahan tersebut baik dalam bentuk kesengajaan ataupun kealpaan.

3. Pidana harus disesuaikan dengan karakteristik dan keadaan si pelaku. Hal ini berarti harus ada kelonggaran/fleksibilitas bagi hakim dalam memilih sanksi pidana (jenis maupun berat ringannya pidana) dan harus ada kemungkinan modifikasi pidana (perubahan/penyesuaian) dalam pelaksanaannya. ${ }^{9}$

7 C. Maya Indah, "Konstruksi Pertimbangan Hakim dalam Penerapan Prinsip Individualisasi Pidana demi Mewujudkan Perlindungan Anak", Jurnal Masalah Masalah Hukum, Vol 43 No. 2, April 2014, Fakultas Hukum Universitas Diponegoro, 2014, Semarang, hal 189. DOI: $\underline{10.14710 / \mathrm{mmh} .43 .2 .2014 .188-196}$

${ }^{8}$ Tri Wahyu Widiastuti, "Prinsip Individualisasi Pidana dalam Hukum Pidana dan Hukum Pidana Islam di Indonesia”, Jurnal Wacana Hukum, Vol 9, No 2, 2010, Fakultas Huykum Universitas Slamet Riyadi, 2010, Solo, hal 45. https://doi.org/10.33061/1.jwh.2010.9.2.275 2002 ), hal. 31.

9 Barda Nawawi Arief, Bunga Rampai Kebijakan Hukum Pidana, (Bandung, Citra Aditya, 
Kebijakan formulasi hukum pidana di bidang perpajakan dalam implementasinmya ternyata menimbulkan berbagai persoalan, terutama terkadengan penerapan ketentuan pasal yang mengatur sanksi pidana. Persoalan tersebut timbul salah satunya dikarenakan penegak hukum dalam melakukan tindakan terhadap suatu perbuatan hukum yang sama menggunakan kebijakan yang berbeda.

Tidak adanya parameter untuk menentukan adanya pelanggaran administrasi dan kejahatan di bidang perpajakan, telah melukai rasa keadilan dan menimbulkan ketidakpastian hukum. Ketidakadilan terjadi manakala seseorang yang karena kelalaian dan ketidaktahuannya terhadap administrasi perpajakan, diancam dan dihukum sama dengan mereka yang sejak semula berniat (mens rea) untuk melalukan kejahatan di bidang perpajakan. ${ }^{10}$

Berbeda dengan penelitian sebelumnya, penelitian ini lebih fokus membahas penerapan ide individualisasi pidana yang dituangkan melalui pemidanaan terhadap pelaku tindak pidana perpajakan dalam ketiga putusan pengadilan sebagaimana yang tertuang dalam Putusan MA No. 938 K/Pid.Sus/2015. Penelitian tentang penerapan individualisasi khusunya dalam tindak pidana perpajakan belum pernah diangkat dalam penelitian sebelumnya. Tujuan dilakukannya penelitian ini adalah untuk menganalisis permasalahan yang berkaitan dengan penerapan prinsip individualisasi pidana melalui pemidanaan terhadap pelaku tindak pidana perpajakan dalam putusan hakim.

\section{B. Perumusan Masalah}

Berdasarkan uraian latar belakang di atas jelas cakupannya sangat luas, guna mencegah luasnya cakupan tersebut, dan untuk memudahkan pembahasan maka permasalahan dalam penelitian ini adalah bagaimanakah penerapan prinsip individualisasi pidana melalui pemidanaan terhadap pelaku tindak pidana perpajakan dalam putusan MA No. 938 K/Pid.Sus/2015?

10 Diajeng Kusuma Ningrum, Budi Ispiyarso, dan Pujiono, "Kebijakan Formulasi Hukum Pidana di Bidang Perpajakan sebagai Upaya Peningkatan Penerimaan Negara”, Jurnal Law Reform Program Studi Magister Ilmu Hukum Universitas Diponegoro, Volume 12, Nomor 2, Tahun 2016, hal 211. https://doi.org/10.14710/lr.v12i2.15875 


\section{METODE PENELITIAN}

\section{Metode Pendekatan}

Metode pendekatan yang akan digunakan dalam penelitian ini adalah pendekatan yuridis normatif, yaitu dengan mengkaji atau menganalisis data sekunder yang berupa bahan hukum primer, dengan memahami hukum sebagai perangkat peraturan atau norma-norma positif di dalam sistem perundang-undangan yang mengatur mengenai penerapan prinsip individualisasi pidana melalui pemidanaan terhadap pelaku tindak pidana perpajakan dalam putusan pengadilan, sekaligus juga menggunakan bahan hukum sekunder, dan tersier. Jadi pembahasan dalam penelitian ini dipahami sebagai kajian kepustakaan terhadap data sekunder.Pendekatan yuridis-normatif dalam kajian ini digunakan untuk menganalisis permasalahan yang berkaitan dengan penerapan prinsip individualisasi pidana melalui pemidanaan terhadap pelaku tindak pidana perpajakan dalam putusan pengadilan.

Adapun putusan pengadilan yang dianalisis berkaitan dengan penerapan prinsip individualisasi pidana melalui pemidanaan terhadap Pelaku Tindak Pidana Perpajakan adalah putusan pengadilan yang sudah berkekuatan hukum tetap, yaitu : Putusan MA No. 938 K/Pid.Sus/2015.

\section{Metode Pengumpulan dan Analisis Data}

Metode pengumpulan data dilakukan melalui studi pustaka. Data tersebut kemudian diidentifikasi dan kategorisasikan, selanjutnya dianalisis dengan metode analisis kualitatif. Dari hasil analisis tersebut kemudian akan ditarik kesimpulan sebagai jawaban atas permasalahan dalam penelitian ini.

\section{PEMBAHASAN}

Di era modern sekarang ini, pemungutan pajak yang sudah terintegrasi dalam sistem digital sebagai standar pemungutan pajak yang lebih efisien dan transparan bagi negara, sebenarnya turut bersumber dari Pasal 23 ayat (2) UUD 1945 yang berbunyi; "Segala pajak untuk keperluan negara berdasarkan undang-undang”. Pasal ini juga memiliki keterkaitan kuat dalam hal perwujudan APBN (Anggaran Pendapatan Belanja Negara) yang spesifik dan 
akuntabel. Jika dikaitkan dengan data realisasi kinerja APBN 2018 (unaudited) yang secara umum dianggap cemerlang, permasalahan tahunan mengenai tidak tercapainya target penerimaan pajak, masih terus berlanjut. ${ }^{11}$

Sebagaimana yang dirumuskan dalam Pasal 5 ayat (1) Undang-Undang No. 48 Tahun 2009 tentang Kekuasaan Kehakiman, yang merumuskan bahwa: "Hakim dan hakim konstitusi wajib menggali, mengikuti, dan memahami nilai-nilai hukum dan rasa keadilan yang hidup dalam masyarakat". Berdasarkan pasal ini, maka hakim adalah sebagai 'sense of justice of the people". Hal ini berarti hakim sebagai penegak hukum dan keadilan wajib untuk terjun ke tengah-tengah masyarakat guna mengenal, merasakan dan mampu menyelami perasaan hukum dan rasa keadilan yang hidup dalam masyarakat. Dengan demikian hakim dapat memberikan putusan yang sesuai dengan hukum dan rasa keadilan masyarakat.

Urgensi pertimbangan hakim dalam penerapan sanksi pidana untuk memenuhi rasa keadilan sangatlah beralasan, dan juga harus ada dan tertulis dalam putusannya, hal ini sebagaimana yang dikemukakan oleh Benedictus Singgih:

a. Bahwa putusan hakim harus berpedoman pada unsur yuridis, filosofis dan sosiologis yaitu mempertimbangkan tata nilai budaya yang hidup dan berkembang dalam masyarakat.

b. Dalam mempertimbangkan berat ringannya pidana, hakim wajib memperhatikan pula sifat baik dan jahat dari terdakwa. Penetapan dan putusan harus memuat pertimbangan hukum hakim yang didasarkan pada alasan dan dasar hukum yang tepat dan benar.

c. Surat putusan pemidanaan harus memuat pertimbangan yang disusun secara ringkas mengenai fakta dan kaedaan, beserta alat pembuktian yang diperoleh dari pemeriksaan di sidang yang menjadi dasar penentuan kesalahan terdakwa. ${ }^{12}$

PT. Shields Indonesia bergerak dalam jasa keamanan pengadaan satuan

\footnotetext{
11 Januardo Sulung Partogi Sihombing, Redivasi Kelembagaan Otoritas Penerimaan Pajak Indonesia Dalam Pembaharuan Sistem Hukum Perpajakan Nasional Yang Progresif, Jurnal Ius Constituendum Vol 5 No 1, Magister Hukum Universitas Semarang, 2020, Semarang, hal 145. http://dx.doi.org/10.26623/jic.v5i1.2093

12 Benedictus Singgih, "Analisis Putusan tentang Pencemaran Nama Baik Melalui Media Elektronik", https://benedictussinggih.blogspot.com/2015/05/analisis-putusan-tentang pencemaran.html, diakses tanggal tanggal 3 Februari 2020.
} 
pengamanan, pelatihan jasa keamanan, konsultasi dibidang keamanan serta penyediaan alat-alat keamanan dengan konsumen perusahaan-perusahaan penamanan modal dalam negeri (PMDN) dan Penamanan Modal Asing (PMA) di wilayah Jawa, Sumatera, Sulawesi, Kalimantan, Bali dan Nusa Tenggara,diduga melakuakn tindak pidana perpajakan yaitu dengan tidak menyetor pajak yang dipungut kepada negara. Kasus tinda pidana perpajakan tersebut melibatkan 3 orang sebagai terdakwa yaitu Tri Anis Noorbaiti, Kenny Douglas Mc Kinney (Telah Divonis) dan Yudi Irawan.

Perbuatan yang dilakukan oleh terdakwa dalam Putusan MA No. 938 K/Pid.Sus/2015 tersebut dapat diuraikan sebagai berikut :

a. Nama Terdakwa : Tri Anis Noorbaiti (TAN)

b. Dakwaan :

Melakukan tindak pidana "tidak menyampaikan surat pemberitahuan dan atau keterangan yang isinya tidak benar atau tidak lengkap, tidak menyetor pajak yang telah dipotong atau dipungut dan tidak menyetorkan pajak yang telah dipotong atau dipungut secara berlanjut" (Pasal 39 Ayat (1) huruf (b), huruf (c) dan huruf (g) jo Pasal 43 UU No. 6 Tahun 1983 tentang KUP sebagaimana yang telah diubah dengan UU No, 16 Tahun 2000 tentang Perubahan kedua atas UU No. 6 Tahun 1983 tentang KUP jo. Pasal 64 Ayat (1) KUHP.

c. Putusan :

Terdakwa terbukti secara sah dan meyakinkan melakukan tindak pidana "tidak menyampaikan surat pemberitahuan dan atau keterangan yang isinya tidak benar atau tidak lengkap, tidak menyetor pajak yang telah dipotong atau dipungut dan tidak menyetorkan pajak yang telah dipotong atau dipungut secara berlanjut" dengan pidana penjara selama 2 (dua) tahun dan 6 (enam) bulan dan denda sebesar Rp. 21.147.803.820,00 (dua puluh satu miliar seratus empat puluh tujuh juta delapan ratus tiga ribu delapan ratus dua puluh rupiah).

Paradigma pemidanaan telah mengalami pergeseran, yaitu beralih pada rasa keadilan yang harus diperoleh semua pihak, hakim tidak hanya terpuaskan untuk memidana pelaku, atau korban yang merasa puas terhadap vonis hakim, 
melainkan juga pelaku memperoleh kesempatan untuk memperbaiki diri dan masyarakat terpuaskan. ${ }^{13}$

Berkaitan dengan hal di atas, penerapan ide individualisasi pidana yang dituangkan melalui pemidanaan terhadap pelaku tindak pidana perpajakan dalam Putusan MA No. 938 K/Pid.Sus/2015 tersebut berdasarkan analisis penelitian ini adalah adanya ketentuan mengenai modifikasi/perubahan/penyesuaian atau peninjauan kembali putusan pemidanaan yang telah berkekuatan hukum tetap yang didasarkan pada adanya perubahan/perkembangan/perbaikan pada diri pelaku sendiri.

Dalam Putusan Mahkamah Agung No. 938 K/Pid.Sus/2015 tersebut telah mendasarkan pada pemikiran mengenai ide individualisasi pidana tidak hanya pada tataran pidana yang dijatuhkan dengan menyesuaikan pada kondisi pribadi/individu, namun sanksi pidana yang telah dijatuhkan dan telah berkekuatan hukum tetap (inkracht van gewijde) dapat pula dilakukan perubahan atau penyesuaian berdasarkan pada perkembangan atau perbaikan individu terpidana serta mempertimbangkan pada tujuan pemidanaan. Pasal 57 ayat (1) Konsep KUHP 2015 menyatakan bahwa "putusan pidana dan tindakan yang telah memperoleh kekuatan hukum tetap dapat dilakukan perubahan atau penyesuaian dengan mengingat perkembangan narapidana dan maksud pemidanaan". Selanjutnya, konsep KUHP 2015 juga memberikan kelonggaran pihak-pihak yang dapat mengajukan permohonan penyesuaian ini, yaitu dapat dilakukan oleh narapidana sendiri, orang tua, wali, penasehat hukum, jaksa penuntut umum atau hakim pengawas (Pasal 57 ayat (2)). Perubahan atau penyesuaian pidana tersebut menurut Konsep KUHP tidak diperbolehkan lebih berat dari putusan semula, dan dapat berbentuk: (a) pencabutan atau penghentian sisa pidana atau tindakan, atau (b) penggantian jenis pidana atau tindakan lainnya. Jika permohonan perubahan atau penyesuaian ini ditolak hakim, baru dapat diajukan kembali satu tahun kemudian setelah penolakan, kecuali dalam keadaan khusus yang

\footnotetext{
13 Y. A. Triana Ohoiwutun dan Samsudi, Op.cit, hal 41.
} 
menunjukkan permohonan kembali tersebut pantas untuk dipertimbangkan.

Sementara itu ketentuan mengenai perubahan atau penyesuaian pidana yang telah dijatuhkan dan telah berkekuatan hukum tetap (inkracht van gewijde) berdasarkan pada perkembangan atau perbaikan individu terpidana dalam Rancangan KUHP 2019 sudah dihapuskan/ tidak lagi dirumuskan dalam pasal Rancangan KUHP 2019, hal ini karena bertentangan dengan asas kepastian hukum.

Berikut ini adalah hasil analisis penelitian ini tentang penerapan ide individualisasi pidana yang dituangkan melalui pemidanaan terhadap pelaku tindak pidana perpajakan dalam Putusan Mahkamah Agung sebagaimana yang tertuang baik dalam Putusan MA No. 938 K/Pid.Sus/2015.

Sebagaimana dipertimbangkan di atas bahwa perbuatan Terdakwa TAN berbasis pada kepentingan bisnis PT. Shields Indonesia (korporasi) yang diwakilinya untuk menghindari Pajak Penghasilan dan Pajak Badan yang seharusnya dibayar oleh karena itu tidaklah adil jika tanggung jawab pidana hanya dibebankan kepada Terdakwa selaku individu akan tetapi sepatutnya juga menjadi tanggung jawab korporasi yang menikmati atau memperoleh dari hasil Tax Evation tersebut;

Sekalipun secara individual perbuatan Terdakwa terjadi karena "mensrea" dari Terdakwa, namun karena perbuatan tersebut semata-mata untuk kepentingan dari korporasi maka Mahkamah Agung berpendapat bahwa apa yang dilakukan oleh Terdakwa adalah dikehendaki atau "mensrea" dari PT. Shields Indonesia (korporasi), sehingga dengan demikian pembebanan tanggung jawab pidana "Individual Liability" dengan "corporate liability" harus diterapkan secara simultan sebagai cerminan dari doktrin respondeat superior atau doktrin "Vicarious Liability" diterapkan pertanggungan jawab pidana kepada korporasi atas perbuatan atau prilaku Terdakwa sebagai personifikasi dari korporasi yang diwakilinya menjadi tugas dan tanggung jawab lagi pula apa yang dilakukan Terdakwa telah diputuskan secara kolektif.

Mahkamah Agung menyadari gagasan menuntut pertanggungjawaban pidana korporasi belum diterima seutuhnya karena alasan yang sangat formal 
bahwa korporasi dalam perkara a quo tidak didakwakan; Namun perkembangan praktek hukum pidana telah mengintrodusir adanya pembebanan pertanggungjawaban seorang pekerja di lingkungan suatu korporasi kepada korporasi di tempat ia bekerja dengan menerapkan pertanggung jawaban fungsional sebagaimana telah dipertimbangkan diatas.

Kaidah hukum yang mengandung nilai-nilai keadilan akan memudahkan bagi hakim dalam menjalankan putusannya, karena dengan integrasi moral yang tinggi seorang hakim dapat menerapkan kaidah hukum tersebut. Namun jika kaidah hukumnya samar bagi hakim, maka terbuka peluang menjatuhkan putusan berdasarkan keadilan dengan menggali nilai-nilai hukum yang hidup dalam masyarakat. ${ }^{14}$

Selanjutnya, dengan perkembangan hukum pajak di Belanda telah pula menerima pertanggungjawaban pidana dari korporasi karena pajak menjadi andalan anggaran pendapatan Negara yang dilandasi pada kepentingan praktis untuk menegakan hukum khususnya terhadap tindak pidana pajak badan atau korporasi, dan Indonesia telah perlu mempertimbangkan untuk mengadopsi sendi-sendi penegakan hukum di sektor perpajakan sebagaimana yang ada di Belanda. Berkaitan dengan sanksi pidana yang dijatuhkan kepada Terdakwa diterapkan sistem pemidanaan Pasal 14 a, 14 b dan 14 c KUHP sekalipun difahami mungkin dipandang tidak tepat, namun hal tersebut mencerminkan titik berat tanggung jawab pidana lebih pada ketentuan pemidanaan yang diatur di dalam undang-undang perpajakan dan tidak pada pendekatan retributif kepada pelaku individualnya tetapi lebih bertitik berat pada rasa keadilan khususnya pembayaran Pajak Pendapatan Penghasilan dan Pajak Badan dari PT. Shields Indonesia tersebut.

Berdasarkan alasan-alasan yang diuraikan di atas Mahkamah Agung berpendapat, bahwa putusan Pengadilan Tinggi Jakarta Nomor : 05/Pid./TPK/

${ }^{14}$ Vivi Ariyanti, “Kebebasan Hakim Dan Kepastian Hukum Dalam Menangani Perkara Pidana Di Indonesia', Jurnal Mahkamah Vol 4 No 2, IAIN Syekh Nurjati, 2019, Cirebon, hal. 170.

http://dx.doi.org/10.24235/mahkamah.v4i2.5374 
2014/PT-DKI tanggal 04 September 2014 yang memperbaiki putusan Pengadilan Negeri Jakarta Selatan Nomor 568/Pid.Sus/ 2013/PN.JKT.SEL tanggal 10 April 2014 tidak dapat dipertahankan lagi, oleh karena itu harus dibatalkan dan Mahkamah Agung akan mengadili sendiri perkara tersebut..

Perbuatan Terdakwa TAN sebagai diatur dan diancam pidana dalam Pasal 39 Ayat (1) huruf (b), huruf (c) dan huruf (g) jo Pasal 43 Undang-Undang Republik Indonesia Nomor 6 Tahun 1983 tentang Ketentuan Umum dan Tata Cara Perpajakan sebagaimana yang telah diubah dengan Undang-Undang Republik Indonesia Nomor 16 Tahun 2000 tentang Perubahan Kedua Atas UndangUndang Nomor 6 Tahun 1983 tentang Ketentuan Umum dan Tata Cara Perpajakan jo Pasal 64 Ayat (1) Kitab Undang-Undang Hukum Pidana.

\section{PENUTUP}

Penerapan ide individualisasi pidana yang dituangkan melalui pemidanaan terhadap Pelaku Tindak Pidana Perpajakan dalam ketiga putusan pengadilan sebagaimana yang tertuang dalam Putusan MA No. 938 K/Pid.Sus/2015 berdasarkan hasil penelitian ini adalah adanya ketentuan mengenai modifikasi/perubahan/penyesuaian atau peninjauan kembali putusan pemidanaan yang telah berkekuatan hukum tetap yang didasarkan pada adanya perubahan/perkembangan/perbaikan pada diri pelaku sendiri. Rekomendasi dari penelitian ini adalah hakekatnya sanksi pidana yang dijatuhkan pada terdakwa atau terpidana pelaku tindak pidana perpajakan diberlakukan sesuai dengan skala besarnya kerugian negara yang ditimbulkan. Hal ini berarti lamanya sanksi pidana penjara mengacu pada skala kerugian negara, sehingga mencerminkan peradilan negara yang menegakkan hukum demi keadilan berdasarkan Pasal 3 ayat (2) UU No. 4 Tahun 2004 tentang Kekuasaan Kehakiman yang telah diubah dengan Pasal 2 ayat (2) UU Nomor 48 Tahun 2009 tentang Kekuasaan Kehakiman, yang menentukan "Peradilan Negara menerapkan dan menegakkan Hukum dan Keadilan berdasarkan Pancasila. 


\section{DAFTAR PUSTAKA}

\section{Buku}

Arief, Barda Nawawi. Bunga Rampai Kebijakan Hukum Pidana. Bandung: Citra Aditya Bakti, 2002.

Hiariej, Eddy OS. Asas Legalitas \& Penemuan Hukum Dalam Hukum Pidana. Jakarta: Erlangga, 2009.

Muladi dan Barda Nawawi Arief. Teori-teori dan Kebijakan Pidana. Bandung: Alumni, 1998.

Saleh, Roeslan. Perbuatan Pidana dan Pertanggungjawaban Pidana Dua Pengertian Dasar Dalam Hukum Pidana. Jakarta: Aksara Baru, 1983.

\section{Jurnal}

Ahmad Bahiej, "Prinsip Individualisasi Pidana dalam Pembaharuan Hukum Pidana Materiel Indonesia", Jurnal Sosio-Religia, Vol. 3, No. 4, Agustus 2004.

D Maya Indah, "Konstruksi Pertimbangan Hakim dalam Penerapan Prinsip Individualisasi Pidana demi Mewujudkan Perlindungan Anak", Jurnal Masalah Masalah Hukum, Vol 43 No. 2, April 2014, Fakultas Hukum Universitas Diponegoro, 2014, Semarang.

DOI: 10.14710/mmh.43.2.2014.188-196

Diajeng Kusuma Ningrum, Budi Ispiyarso, dan Pujiono, "Kebijakan Formulasi Hukum Pidana di Bidang Perpajakan sebagai Upaya Peningkatan Penerimaan Negara", Jurnal Law Reform Program Studi Magister Ilmu Hukum, Volume 12, Nomor 2, Tahun 2016, Semarang. https://doi.org/10.14710/lr.v12i2.15875

Januardo Sulung Partogi Sihombing, Redivasi Kelembagaan Otoritas Penerimaan Pajak Indonesia Dalam Pembaharuan Sistem Hukum Perpajakan Nasional Yang Progresif, Jurnal Ius Constituendum Vol 5 No 1, Magister Hukum Universitas Semarang, 2020, Semarang. http://dx.doi.org/10.26623/jic.v5i1.2093

Tri Wahyu Widiastuti, "Prinsip Individualisasi Pidana dalam Hukum Pidana dan Hukum Pidana Islam di Indonesia", Jurnal Wacana Hukum, Vol 9, No 2, 2010, Fakultas Huykum Universitas Slamet Riyadi, 2010, Solo. https://doi.org/10.33061/1.jwh.2010.9.2.275

Vivi Ariyanti, "Kebebasan Hakim Dan Kepastian Hukum Dalam Menangani Perkara Pidana Di Indonesia', Jurnal Mahkamah Vol 4 No 2, IAIN Syekh Nurjati, 2019, Cirebon. http://dx.doi.org/10.24235/mahkamah.v4i2.5374

Y. A. Triana Ohoiwutun \& Samsudi, Penerapan Prinsip "Kepentingan Terbaik Bagi Anak" Dalam Kasus Tindak Pidana Narkotika, Jurnal Yudisial, 
Vol 10 No. 1, Komisi Yudisial RI, 2017, Jakarta, hal 189. http://dx.doi.org/10.29123/jy.v10i1.41

\section{Peraturan Perundang-undangan}

Sekretariat Negara RI. Undang-Undang No. 1 Tahun 1946 tentang Peraturan Hukum Pidana (KUHP). Jakarta, 1946.

Sekretariat Negara RI. Undang- Undang Nomor 6 Tahun 1983 tentang Ketentuan Umum dan Tata Cara Perpajakan. Jakarta, 1983.

Sekretariat Negara RI. Undang- Undang Nomor 9 Tahun 1994 tentang Perubahan atas Undang- Undang Nomor 6 Tahun 1983 tentang Ketentuan Umum dan Tata Cara Perpajakan. Jakarta, 1994.

Sekretariat Negara RI. Undang- Undang Nomor 16 Tahun 2000 tentang Perubahan Kedua atas Undang- Undang Nomor 6 Tahun 1983 tentang Ketentuan Umum dan Tata Cara Perpajakan. Jakarta, 2000.

Sekretariat Negara RI. Undang- Undang Nomor 28 Tahun 2007 tentang Perubahan Ketiga atas Undang- Undang Nomor 6 Tahun 1983 tentang Ketentuan Umum dan Tata Cara Perpajakan. Jakarta, 2007.

Sekretariat Negara RI. Undang- Undang Nomor 16 Tahun 2009 tentang Penetapan Peraturan Pemerintah Pengganti Undang-Undang Republik Indonesia Nomor 5 Tahun 2008 tentang Perubahan Keempat atas Undang- Undang Nomor 6 Tahun 1983 tentang Ketentuan Umum dan Tata Cara Perpajakan Menjadi Undang-Undang. Jakarta,, 2009.

Sekretariat Negara RI. Peraturan Pemerintah Pengganti Undang-Undang Republik Indonesia Nomor 5 Tahun 2008 tentang Perubahan Keempat atas Undang- Undang Nomor 6 Tahun 1983 tentang Ketentuan Umum dan Tata Cara Perpajakan. Jakarta, 2000.

\section{Internet}

Benedictus Singgih, "Analisis Putusan tentang Pencemaran Nama Baik Melalui Media Elektronik",

https://benedictussinggih.blogspot.com/2015/05/analisis-putusan-tentang pencemaran.html, diakses tanggal tanggal 3 Februari 2020 